ISSN 0975-3311

UJBM, Vol. 8, No. 2, July - December 2009, pp 24-39

https://doi.org/10.12725/ujbm.15.3

\title{
COMMODITY FUTURES-AN INDIAN EXPERIENCE
}

\author{
G. Prahlad Chowdri* \& C.S. Basavarai**
}

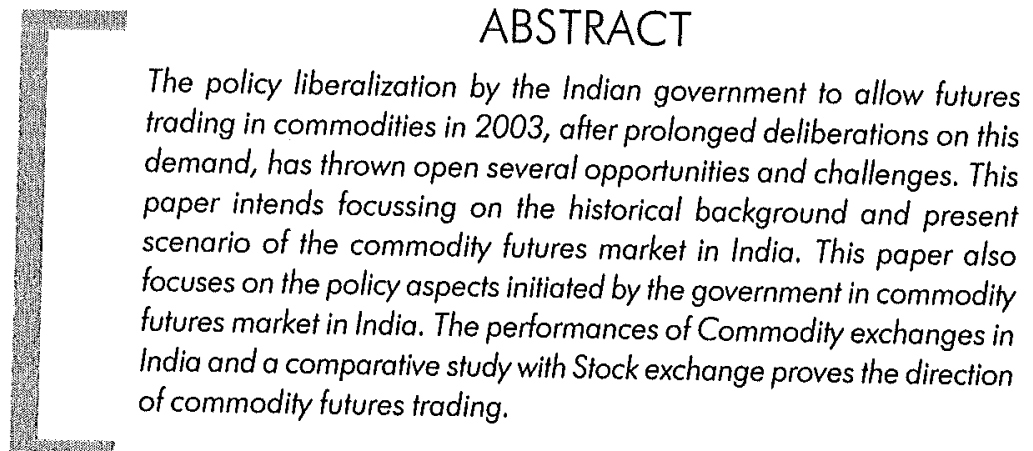

\section{Introduction}

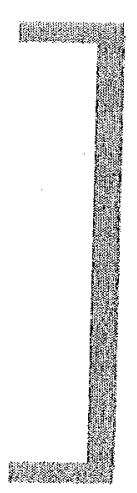

The introduction of derivative trading in commodities in India has thrown open new opportunities and challenges to the economy. After a prolonged and thorough study of the prevailing conditions by several expert groups and committees, finally, the Government of India has allowed 'futures' in

\footnotetext{
* Dept. of Commerce and Management, Govt. First Grade College, HSR Lay-out, Banglaore.

** P.G. Dept. of Studies in Commerce, Gulbarga University, Gulbarga, Karnataka.
} 
commodities in the year 2003, in selected commodities, through national level commodity exchanges. The futures trading in commodities are not new to India, but reintroduction and expansion of the same has opened discussions on concept, development and issues associated with it. The liberal economic policy and opening up and integration of Indian financial and commodities markets with world markets have certainly necessitated studies vis-à-vis derivative trading in commodities.

\section{History of Commodity Derivatives}

Commodity Derivatives are traded through common platform called 'Derivative Exchange'. A derivatives exchange is a market where 'individuals' trade standardized contracts that have been defined by the exchange. Derivatives exchanges have existed for a long time. The Chicago Board of Trade (CBOT) was established in 1848 to bring farmers and merchants together. Initially, its main task was to standardize the quantities and qualities of the grains that were traded. Within a few years, the first futures-type contract was developed. It was known as to-arrive contract. Speculators soon became interested in the contracts and found trading the contract to be an attractive alternative to trading the grain itself. A rival futures exchange, the Chicago Mercantile Exchange (CME) was established in 1919. Now 'derivative exchanges' exist all over the world.'

The Chicago Board of Exchange (CBOE) started trading call option contracts on 16 stocks in 1973. Options had traded prior to 1973, but the CBOE succeeded in creating an orderly market with well-defined contracts. 'Put Option' contracts started trading on the exchanges in 1977. The CBOE now trades Options on well over 1,000 stocks and many different 'Stock Indices'. Like Futures, Options have proved to be very popular contracts. Many other exchanges throughout the world now trade Options. The underlying assets include foreign currencies and futures contracts as well as stocks and stock indices.

The institution of formal commodity futures market in India is almost as old as in the USA and UK. The Indian experience, however, is much older as references to such markets in India appear in Kautialya's Arthasastra. The first organized futures market was established in 1875 under the aegis of the 'Bombay Cotton Trade Association' to trade in cotton contracts which was followed by oilseeds \& food grains. Before the Second World War, a large number of commodity exchanges were trading Futures contracts in 
several commodities like Cotton, Groundnut, Groundnut oil, Raw jute, Jute goods, Castor seed, Wheat, Rice, Sugar, Precious metals like Gold and Silver.

During the Second World War, Futures trading in India was prohibited. After independence, especially between the second half of the 1950s and first half of 1960s, commodity Futures trading again picked up. However, due to shortages during the early and mid-sixties Futures Trading in most of the Commodities was prohibited.

After Independence, the Constitution of India placed the subject of "Stock Exchanges and Futures Market" in the Union list and therefore the responsibility for regulation of forward contracts devolved on Government of India. The Parliament passed Forward Contracts (Regulation) Act, 1952. The Forward Markets Commission (FMC) was established in 1953 under the Ministry of Consumer Affairs and Public Distribution. The Forward Contracts (Regulations) Act, 1952, governs commodity derivatives trading in India. FMC is a regulatory authority, which regulates and recognizes and/or withdraws the recognition of commodity exchanges in India. The FMC also monitors and supervises the activities of commodity exchanges in India.

\section{Policy Liberalization towards Commodity Derivatives in India}

Forward trading was banned in 1960s except for Pepper, Turmeric, Castor seed and Linseed. Futures trading in Castor seed and Linseed were suspended in 1977. Apparently on the basis of the recommendations made by Khusro Committee, 'Forward Trading' in Potato and Gur was allowed in early 1980s and in Castor seed in 1985.

After the process of liberalization initiated in 1990, the Government set up a Committee under the Chairmanship of Prof. K. N. Kabra in 1993 to examine the role of futures trading in the context of liberalization and globalization.

The Kabra Committee recommended the following:

- Allowing futures trading in 17 commodity groups,

- It also recommended strengthening of Forward Markets Commission and amendments to Forward Contracts (Regulation) Act, 1952, 
- The major amendments include allowing options in goods,

- Increase in outer limit for delivery,

- Payment from 11 days to 30 days for the contract to remain ready delivery contract,

- Registration of brokers with Forward Markets Commission.

The Government accepted most of these recommendations and futures trading have been permitted in all the recommended commodities except Bullion and Basmati Rice. Additional staff was provided to the FMC and the post of Chairman was upgraded to the level of Additional Secretary to the Government of India.

With the gradual withdrawal of the government from various sectors in the post-liberalization era, the need has been felt that various operators in the commodities market be provided with a mechanism to hedge and transfer their risks. India's obligation under WTO to open agriculture sector to world trade would require futures trade in a wide variety of primary commodities and their products to enable diverse market functionaries to cope with the price volatility prevailing in the world markets. This has led to the appointment of several committees and expert groups by the government to look into the matter of futures trading in commodities in India.

An Expert Committee on Agricultural Marketing headed by Shankerlal Guru recommended linkage of 'spot and forward' markets, introduction of electronic warehouse receipt system, inclusion of more and more commodities under futures trading and promotion of national system of warehouse receipt. The sub-group on forward and futures markets formed under the Chairmanship of Dr. Kalyan Raipuria, Economic Adviser, Department of Consumer Affairs to examine the feasibility of implementing the recommendations made by the Expert Committee chaired by Shankerrlal Guru recommended that the commodity specific approach to the grant of recognition should be given up. The Exchanges, which meet the criteria, to be stipulated by the Government, should be able to trade contracts in any permitted commodity. In the Budget speech made on 28th February 2002, the Finance Minister announced expansion of futures and forward trading to cover all agricultural commodities. The economic survey for the year 2000-2001 indicated the intention of the Government to allow futures trading in Bullion. The policy statements announced by the Government indicate its resolve to introduce reforms in commodity sector. A number of 
initiatives were also taken to decontrol the spot markets in commodities. The commodities listed as essential commodities have been pruned down to minimum number to facilitate futures trading in more commodities especially in agri-based commodities.

The government has now allowed national commodity exchanges, similar to the Bombay Stock Exchange (BSE) and the National Stock Exchange (NSE), to come up and let them deal in commodity derivatives in an electronic trading environment. These exchanges are expected to offer a nation-wide anonymous, order-driven, screen-based trading system.

As of now three national level commodity exchanges have been approved to commence business in this regard. They are:

- Multi Commodity Exchange of India Ltd (MCX), located at Mumbai.

- National Commodity and Derivatives Exchange Ltd (NCDEX), located at Mumbai.

- National Multi Commodity Exchange (NMCE), located at Ahmedabad.

There are at present 21 regional commodities exchanges operating in India. The Forward Markets Commission (FMC) will regulate these exchanges. The structure of Indian commodity futures market is shown below:

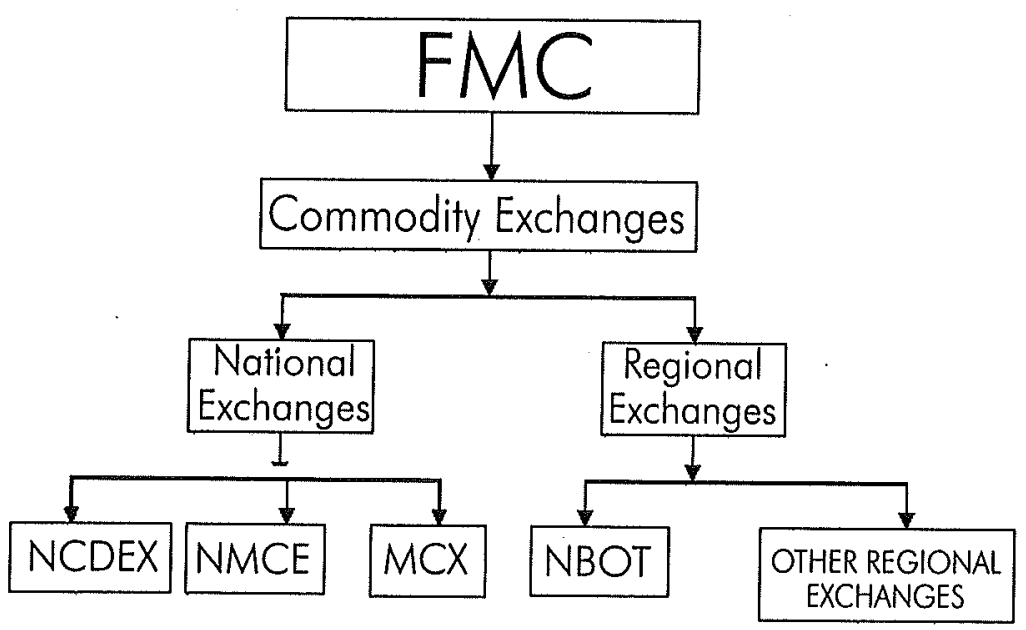

COMMODITY FUTURES MARKETS STRUCTURE 


\section{Need for Derivative trading in Indian commodity markets}

Till 1990s Indian commodity markets were strongly controlled by Government regulations and administered price regime. The restrictive policy and legal framework (in the past) had affected competitiveness of our industry and trade by providing the comfort of security and protection. The process of liberalization and globalization has removed the comfort and unleashed competitive challenges for the Indian industry and trade. In the changed environment, the need to develop and sustain competitiveness has become critical for survival.

'The development and sustenance of competitiveness critically depends on the ability of the trade and industry to make accurate price forecasts in the days to come and transfer the risks related to movement in prices of its inputs / outputs.'

This requires provision of a new set of institutions and practices, which can provide efficient price forecast and also a mechanism to transfer the risk of adverse price fluctuations. The efficient price forecasts help the trade and industry to plan their inventory, production and commitments for sale at a future date. Availability of an efficient formal mechanism to transfer price risk reduces price uncertainty and hence trade and industry can concentrate on their core activity, i.e., trading and manufacturing for earning their margins. In the absence of facilities to forecast prices and transfer price risks, the trade and industry willy-nilly has either to depend on his luck for favorable fluctuations in prices or include risk/uncertainty premium in the price charged from the customers. Similarly it would purchase the inputs from suppliers after incorporating an appropriate risk-discount from the purchase price. This increases the price-spread between the price paid and price received. Such wide price-spreads are symptomatic of inefficient trade and industry and are not sustainable in the changed environment. ${ }^{2}$

An efficient futures market seeks to create an efficient forecast of price, which takes into account all the price-sensitive information about the commodity that, is available at a particular point of time. This is made possible through convergence of bids and offers emanating from all over the country, and even the world, in a trading ring (the single order book of the electronic trading platform) of an exchange. The transfer of price risk is facilitated by the exchange because it is possible to lock in the price of 
future purchase or sale through the trading platform of the exchange. An efficient exchange ensures that distortions in futures prices do not take place and therefore futures and spot prices tend to move in tandem. On the last day of a futures contract, the ready or spot price and the futures prices converge. In view of these features of the futures market, it provides an opportunity to the trade and industry to protect their prices without necessarily having to routing their physical transactions through the exchange. ${ }^{3}$

Mr.Frida Youssef ${ }^{4}$ has made the following two important observations on commodities futures before giving his recommendations in the report to the World Bank on Indian commodity futures markets. They are:

\section{A. Situation of the Indian Commodity Exchanges}

The salient features are,

- India does not have a large nation-wide commodity market, but isolated regional commodity markets based on commodity, crop, etc.

- Indian commodity futures markets are too dispersed and fragmented, with separate trading communities in different regions and with little contact with one another.

- The exchanges have varying degrees of success; the industry is generally viewed as unsuccessful.

- The exchanges - with a few exceptions - have acknowledged that they need to embrace new technologies, and, above all, modern - and transparent - methods of doing business. But management often finds it difficult to chart out a route into the future, and have had difficulties in convincing their membership.

- Next to the officially approved exchanges, there are many 'hawala' markets. Most of these unofficial commodity exchanges have operated for many decades and have built up a reasonable reputation in terms of integrity and liquidity.

- Many market participants feel that as this system has worked well for a long time, there is no reason to fear a breakdown of this system based on trust. However, this clearly cannot be the base for government policy, which has a duty to protect the public against the risks that use of these markets pose. 


\section{B. International Trends}

India has adopted liberal economic policy and opened doors for foreign investment in its markets. This has resulted in large flow of foreign funds added with domestic surplus funds needed an alternative investment markets to stock markets. Moreover, as a result of globalization and liberalization, more and more farmers and traders are becoming exposed to the vagaries of world commodity prices, and to heightened international competition. As a result, the importance of commodity exchanges and other tools for the transfer of risk (essential elements of an efficient market place) is increasing. Meanwhile, developments in, primarily, technology and communications are driving a drastic upheaval of the commodity exchange sector. Key factors affecting exchanges include:

- The trend towards electronic trading; even the exchanges that have a legacy of open outcry (and the concomitant problem of floor brokers keen on defending their turf) are now moving towards electronic trading.

- The emergence of Internet-based commodity exchanges and Electronic Communication Networks (ECNs) using a combination of dedicated networks and the Internet, as competitors to exchanges.

- Globalization of financial markets, where players now use multiple products on multiple exchanges.

- Few new products available for futures exchanges to launch.

The need for derivative trading in commodities in India is thus very essential and it can be further justified by evaluating the pros and cons of spot commodity trading as well as studying the economic functions of commodity derivative markets.

\section{Spot Commodity Trading in India}

The 'Spot Markets' are also called cash markets or Over the Counter trading markets (OTC). "The cash market is the market for buying and selling physical commodity at a negotiated price. Delivery of the commodity takes place immediately or at a pre-decided forward date".

A 'Cash' or 'Spot' contract is also called 'Ready Contract' and the payments are made immediately or within a short period after the contract are entered between the contracting parties. 
The OTC markets are essentially spot markets and are localised for specific commodities. Almost all the trading that takes place in these markets is delivery based. The buyers as well as the sellers have their set of brokers who negotiate the prices for them. In the event of a deal taking place, the goods and the money would be exchanged directly between the buyer and the seller. Thus, it can be seen that this market is restricted to only those people who are directly involved with the commodity. The spot markets are the oldest form of commodity markets in India and the world. These commodity markets play a vital role in every economy and are pillars of distribution of wealth from place of origin to the place of utility or consumption. Well developed commodity markets are essential for achieving goal of economic development. Spot commodity markets are broadly classified in to the following:

\section{Consumer goods and/or commodities markets.}

2. Agricultural commodities markets,

3. Industrial commodities markets.

The consumer commodity markets facilitate the physical transfer of goods along with their ownership from manufacturer to consumers. Different middlemen or chain of intermediaries help in the above task. The consumer commodities or goods are meant for final consumption viz., soaps, milk, meat, fruits, etc., which are either processed before reaching to the consumer or directly brought to the consumer with or without some basic processing.

The agricultural commodity markets serve both individual consumers as well as industrial or manufacturing sector with wide range of agro-based products or commodities. Further, these agricultural commodities are sold once they are harvested or minimum process is undertaken to make them fit to sell in the market. Agricultural commodity markets are basically regulated in India, by government through setting up of different markets for each kind of agricultural commodity. Another important feature of agricultural commodity market is that these are set-up through co-operative societies or organizations and are supervised by Government Agencies. Examples of these markets are Agricultural Producers Market Committees [APMC's], Cotton Corporation of India [CCl], etc.

The industrial commodity markets serve the requirement of manufacturing and other allied sectors. Industrial commodities are mostly sold directly to the users and/or otherwise with less number of intermediaries. 
Problems of Spot market: A well organized and efficient spot market structure is essential for growth of economy and improving standard of living of people. ${ }^{6}$ However, some important lacunas of spot markets in India, especially in agricultural markets are as follows: ${ }^{4}$

- All agricultural commodities in India trade in wholesale markets or 'mandis' where the price of the commodities are set. If it is a 'principal commodity' and market determined price is below a threshold (MSP), the trader has to take the delivery at the MSP. In return, the trader is compensated by the mandi which in turn, compensated by the government.

- The industrial commodities are to be procured from different geographical corners of the world based on their availability and hence subject to price and other risks.

- Price dissemination is another important problem of spot markets. Every mandi becomes a monopoly to the local producers, especially once they come to the market which leads price discrimination.

- Prices can be quoted and compared across the country once there is a good standardization of commodities. But, Indian agri-commodity markets lack standards and certification.

In addition to the spot transactions, forward deals also take place in these markets. However, they too happen on a delivery basis and hence are restricted to the participants in the spot markets. It is to ensure that he gets supplies at the set price. Forward Contracts evolved in the early stages of development of mercantile activity to cater to the needs of a manufacturer, processor or producer where giving and taking actual delivery of goods at a specified price and a specified future date is essential.

\section{Regulatory Issues}

'Futures trading is the best bet for price discovery, and must not be banned. Surely, tough regulations and safety measures are necessary. ${ }^{7} \mathrm{~A}$ draft bill has been submitted by the Parliament Standing Committee to the Parliament during 2006 for the amendment act called, 'The forward Contracts (Regulation) Amendment Bill, 2006'. The proposal seeks to make the following amendments to the Forward Contracts (Regulation) Act, 1952, to,- 
(a) amend the definition of the expression "forward contract" so as to include therein "commodity derivative" and also insert new expressions such as "commodity derivative", "corporatisation", "demutualization". and "intermediary", etc.; which have been used in the Bill;

(b) Increase the maximum number of members of FMC from four to nine out of which three to be whole-time members and a Chairman;

(c) Confer power upon the FMC to levy fees;

Apart from the above, a number of other proposal's were made including demutualization and corporatisation of exchanges, efc. Many of the proposed amendments were being implementing gradually by the Central Government.

\section{Overview of commodity exchanges in India:}

India has a long history of commodity exchanges dating back to 18th century when the first organized exchange was established in 1875 under the aegis of the 'Bombay Cotton Trade Association' to trade in cotton contracts which was followed by oilseeds \& food grains. At present, there are 24 commodity exchanges working in India, three national level and 21 regional exchanges under the regulation of Fonward Markets Commission (FMC). The national level commodity exchanges are serving the traders, farmers and the investors with nation-wide coverage by online real-time trading platform and becoming popular among all sections of commodity markets. The details of the three large national exchanges are summarized as below:

Multi-Commodity Exchange (MCX), headquartered at Mumbai, promoted by FT, SBI, UBI, NSE, NABARD, HDFC Bank, and other financial institutions. At present, more than 50 commodities are listed and major traded commodities are Gold, Silver, Soya, Crude Oil, Mentha Oil, etc, with an average daily turnover of over Rs. 3000 crores. The hours of trading at $M C X$ are $10 \mathrm{am}$ to $5 \mathrm{pm}$ for agro commodities and $10 \mathrm{am}$ to 11.30 pm for metal commodities.

National Commodities Derivative Exchange (NCDEX),
headquartered at Mumbai, promoted by NSE, ICICI Bank, CRISIL, Canara
Bank, PNB, and other financial institutions. At present, more than 50
commodities are listed and major traded commodities are Guar Seed, 
Guar Gum, Chana, Silver, Gold, Soya, etc, with an average daily turnover of over Rs, 3000 crores. The hours of trading are $10 \mathrm{am}$ to $5 \mathrm{pm}$ for agro commodities and $10 \mathrm{am}$ to $11.30 \mathrm{pm}$ for metal commodifies.

National Multi-Commodity Exchange (NMCE), headquartered at Ahmedabad, promoted by CWC, NAFED, PNB and other organizations. At present, more than 60 commodities are listed and major traded commodities are Rubber, Pepper, Cardamom, Jute, Coffee, etc, with an average daily turnover of over Rs. 100 crores. The hours of trading at NMCE are between 10 am to $5 \mathrm{pm}$ for all commodities.

Apart from the above, regional exchanges are also functioning across the country listing with local commodities, basically agri-commodities.

Market Trends: The introduction of 'commodity future trading' in India has cerlainly opened new opportunities for investors as well other participants like brokers, dealers, warehousing, etc. An evaluation of trading information 'reveals that 'commodity future market' is gaining prominence. The two national level exchanges viz, MCX and NCDEX lead in terms of both volumes and value in the market. Initially, NCDEX recorded high turnover due to trading in many agri-commodities. After imposition of ban on future - trading in several agri-commodities, the turnover has declined and paves the way for $M C X$, which is aggressive in metals and other non-agricultural commodities.

At present over 100 commodities are being traded on several exchanges in India. The metal and crude oil contracts are contributing major share in the volumes of major exchanges.

Tabél 1 : Turnoyer of Commodity Furures Markets in India (Rupees in crores)

\begin{tabular}{|r|l|r|r|r|r|r|}
\hline SI. & Exchanges & $2004-05$ & $2005-06$ & $2006-07$ & $2007-08$ & $2008-09 *$ \\
\hline No. & & $165,147.00$ & $961,633.00$ & 2195205.51 & 3240256.754 & 757549.02 \\
1. & MCX & $266,338.00$ & $1,066,686.00$ & 1095229.93 & 775590.65 & 115384.11 \\
2. & NCDEX & $13,988.00$ & $18,385.00$ & 105669.316 & 25414.748 & 7782.196 \\
3. & NMCE & $126,286.00$ & $108,418.00$ & 99691,524 & 24727.318 & $12,723.60$ \\
4. & Others & & & & \\
\hline 5. & AllExchanges & & & & & \\
& (TOTAL) & $571,759.00$ & $2,155,122,00$ & 3495796.28 & 4065989.47 & 893438.93 \\
\hline
\end{tabular}

* Till 16th June 2008

Source - Forward Market Commission 
Chart 1 - Annual Turnover of Exchanges

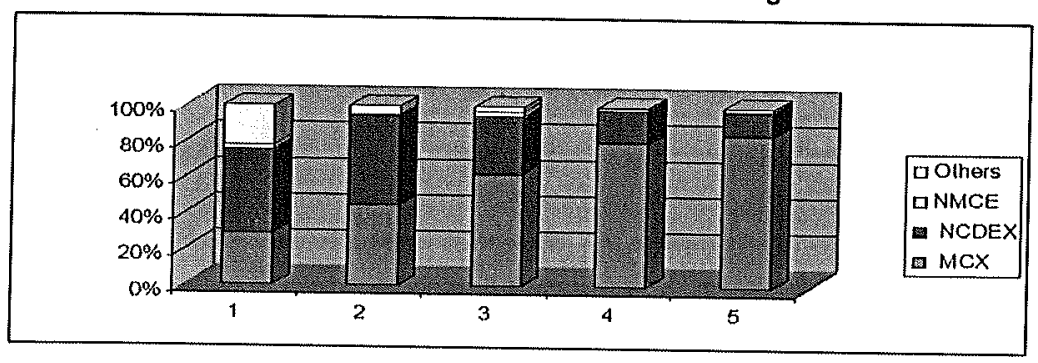

Chart 2- Total turnover of All Commodity Exchages in India

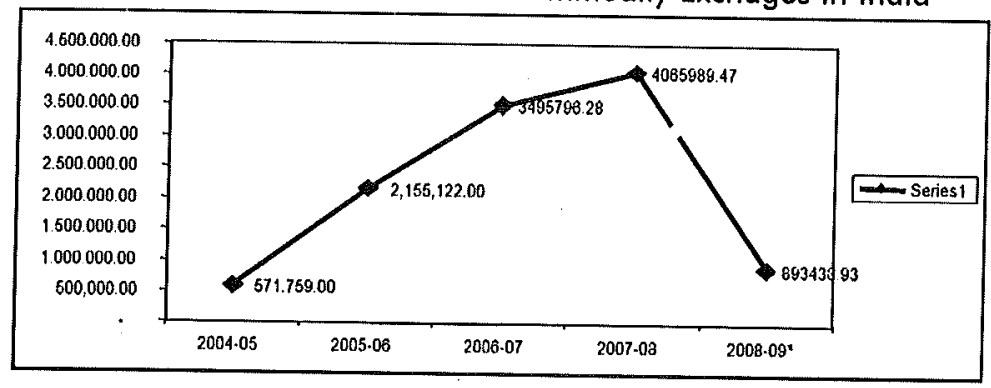

As the world economy plunges in recent times the volumes in Indian Commodity Exchanges have also drastically come down (see chart-2). The two leading exchanges viz. Multi Commodity Exchange (MCX) and National Commodity and Derivative Exchange (NCDEX) have accounted for major share of turnover in Indian commodity futures market. The NCDEX is a leading exchange for agri-commodities whereas; the MCX is the leader in metal and oil commodities. The turnover of NCDEX is shown in chart-3 as under:

\section{Chart 3 - The furnover of NCDEX}

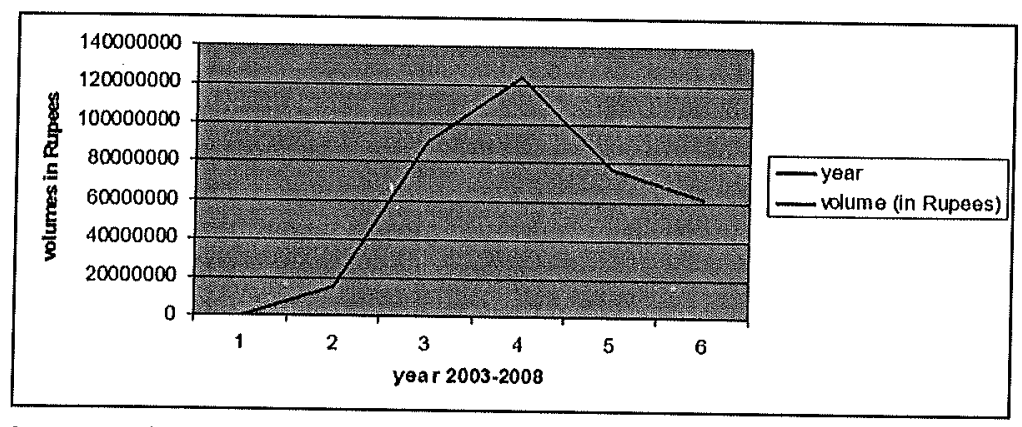

Source: website of 'National Commodity and Derivative Exchange' (NCDEX) 
The turnover of NCDEX has declined in recent times due to recession in economy and intervention of government by banning of trading in several agri-commodities on the apprehension that futures in commodities have led to price rise. Some of the banned commodities for futures trading are wheat, tur dal, etc.

The other leading commodity exchange in India, the $M C X$, has greatly achieved success by introducing contracts in wide range of products such as metal, agri, oil, weather, carbon, etc. A careful study of its benchmark index COMDEX (FUTURES) and COMDEX (SPOT) emphases that the spot and futures prices are moving together. (See Chart-4 below).

Chart 4 - Showing comdex movement of sport and futures prices

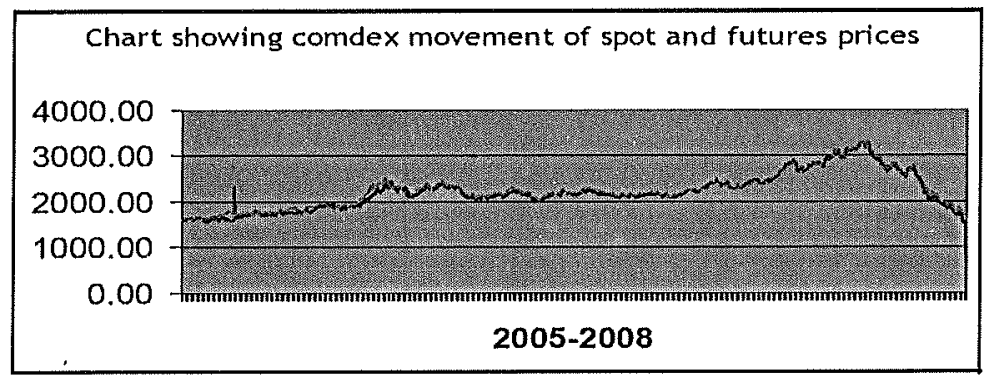

Source: Website of MCX

An evaluation of bench mark stock index NIFTY and commodity index COMDEX below (chart-5) shows that the stock markets and commodity markets have moved in opposite direction initially. However, both have moved down in recent days due to economic recession and have almost giving same returns. (Please note that no trading is done on COMDEX).

Chart 5 - Shows that the stock markets and commodity markets have moved in opposite direction initially

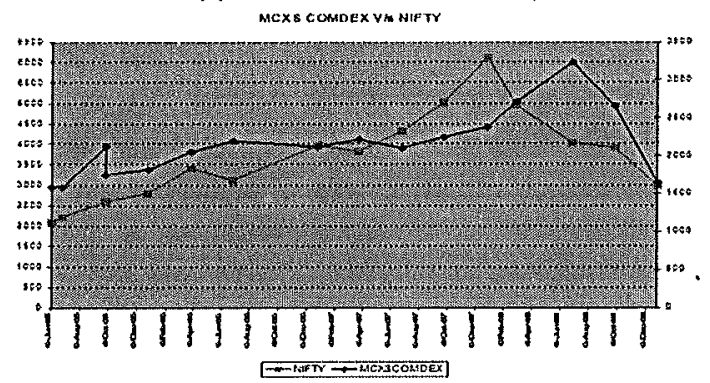

Source: websites of NSE and MCX 


\section{Some recent developments}

- In the union budget 2008-09, the government has proposed a commodity transaction tax (CTT) of $0.017 \%$ which would increase total transaction cost of futures trading in commodity markets. It remains to study the impact of this tax on the 'Commodity Futures Trading' in India.

- Many committees and expert groups are working on the impact of Futures Trading. The studies are being conducted on areas such as impact futures trading on prices of agricultural commodities, government intervention on futures trading, transaction tax on commodities futures trading, etc.

- The leading commodities exchanges viz. MCX and NCDEX have setup their own separate spot exchanges to facilitate spot trading on nationwide online trading basis.

- The FMC has come out with several guidelines to improve the 'Futures Markets' in India. The initiatives include, 'de-mutualisation' process of commodity exchanges, dissemination of trading data, education of participants, etc.

- The regulation of 'Futures Markets' is under the subject of Union Government whereas the 'Spot Markets' is the subject matter of concerned State Government. Many state governments have amended APMC Act to facilitate the functioning of Spot Electronic Commodity Exchanges.

\section{Conclusion}

Initially due to excessive pressure on stock market on account of large flow of funds, the investors were desperately looking for alternative investment opportunities. By allowing futures in commodities and giving permission for setting up of national level online-trading commodity exchanges, a huge forward step has been taken in the history of Indian markets. Later, due to recession in economy and fall of stock market, the investors have shown interest in commodity futures markets. However, it is very important to safeguard the interest of the investors and create a transparent trading atmosphere. Efforts should be made to attract more participants especially the 'farming community' to use commodity futures trading for their benefit, The FMC should also encourage creation of 'commodity specific association' or 'bodies' to promote overall development of futures trading. 


\section{References and End Notes:}

-1 John C. Hull, 'Options, Futures and Other-Derivatives', Prentice-Hall of India, p.2.

2 Kailash R. Gupta, Managing Director, National Multi-Commodity Exchange of India Ltd.

3. Kailash R. Gupta, Managing Director, National Multi-Commodity Exchange of India Ltd.

4 Mr. Frida Youssef, a consultant, in his report titled 'Integrated report on Commodity Exchanges and Forward Market Commission (FMC)' submitted during October-2000 to the World Bank under 'World Bank Project for improvement of the Commodities Futures markets in India' has emphasized the need of efficient and well organized commodities futures trading in India.

5 Source from www.mexindia.com, website of Multi Commodity Exchange of India.

6. Susan Thomas, Agricultural commodity markets in India; Policy issues for growth, May 21, 2003.

7 Bharath Jhunihunwala, Dated on23/10/2006, in Business Line. 